\title{
STIMULATION OF CREATIVITY POTENTIAL AND AMBIGUITY TOLERANCE AS EFFECTIVE FOREIGN LANGUAGE TEACHING PREDICTORS
}

\section{[STIMULACIA TVORIVEHO POTENCIALU A TOLERANCIE NEJEDNOZNACNOSTI AKO PREDIKTOROV ZEFEKTIVNENIA CUDZOJAZYCNEJ VYUCBY]}

\section{Eva Mala - Daniela Muglova - Eva Stranovska}

doi: 10.18355/PG.2019.8.1.11

\begin{abstract}
Creativity from the cognitive point of view in teaching foreign languages is analyzed in the paper. Cognitive theories of creativity are presented by means of cognitive styles theories, namely, the variable of ambiguity tolerance, by mental stimulation theory and creative transdisciplinary thinking. Dynamics of ambiguity tolerance by the help of a creativity program in teaching foreign languages is discussed. It introduces a method of active social learning, autonomous learning, specific methods of creativity and learning foreign languages. The scale of the Ability to Achieve Cognitive Structure (AACS) was applied in the sample of 102 students at Constantine the Philosopher University in Nitra.
\end{abstract}

\section{Key words}

ambiguity tolerance, creativity program, teaching foreign languages

\section{Anotácia}

Príspevok sa zaoberá analýzou kreativity z kognitívneho aspektu vo vyučovaní cudzieho jazyka. Kognitívne teórie kreativity sú prezentované prostredníctvom teórie kognitívnych štýlov, konkrétne premennou tolerancia nejednoznačnosti, teórie mentálnej stimulácie a kreatívneho transdisciplinárneho myslenia. Dynamika tolerancie nejednoznačnosti je zist'ovaná pomocou programu tvorivosti v cudzom jazyku, ktorý predstavuje metódu aktívneho sociálneho učenia, autonómneho učenia, špecifické metódy kreativity a učenia sa cudzieho jazyka. Vo výskumnej vzorke 102 študentov Univerzity Konštantína Filozofa v Nitre bola použitá Škála schopnosti vytvorenia kognitívnej štruktúry (AACS).

\section{Kl'účové slová}

program tvorivosti, tolerancia nejednoznačnosti, výučba cudzieho jazyka

\section{Úvod}

Kreativita vo vyučovaní cudzieho jazyka predstavuje základný rámec pedagogického pôsobenia, pretože učenie sa cudzieho jazyka implikuje zložitost', širokospektrálnost' procesov jednotlivca a najmä hlbokú individualitu. Tak ako nenájdeme dvoch identických jednotlivcov, nenájdeme ani dva rovnaké spôsoby cudzojazyčného prejavu. Jazyk 
reprezentuje nepretržitú tvorbu, jedinečný a neopakovatel'ný obraz l'udskej kognície. Z toho dôvodu výskum v oblasti kreativity v cudzojazyčnej výučbe z kognitívneho pohl'adu (Liu, 2012; Clarke, 2012; Stranovská a kol., 2013; Bírová, 2013; J. Henriksen, Mishra, Fisser, 2016, Müglová, Malá, Stranovská 2017 a i.) predstavuje neobmedzené pole pôsobnosti, bádania, dedukcií a indukcií. Reálna prax prípravy budúcich učitel’ov pre základné a stredné školy (Lalinská, 2013a; Bírová, Eliášová 2014; Gadušová, Hašková, 2015 a i.) a nadväzne aj medzinárodné testovania učebných výsledkov žiakov základných a stredných škôl (Lalinská, 2013b; Gadušová, Hašková, 2015) ukazujú, že $\mathrm{v}$ tomto smere máme $\mathrm{v}$ našom vzdelávacom procese rezervy. Je evidentné, že model Root-Bernsteinovej teórie kreatívneho transdisciplinárneho myslenia (Root-Bernstein, 2003; Henriksen, Mishra, Fisser, 2016) a model kreatívnej koncepcie vyučovania cudzieho jazyka (Clarke, 2012; Birdsell, 2013; Runco, 2014), ktorý spĺn̆a kritériá aktuálnych požiadaviek na vzdelávanie sa dostatočne nereflektuje $\mathrm{v}$ bežných podmienkach školy.

Jednou z ciest ako zatraktívnit' a zefektívnit' edukačný proces je integrácia tvorivých metód do výučby, ktoré sa koncentrujú na kognitívnu stimuláciu, pričom podnecujú vnútornú motiváciu a myšlienkovú flexibilitu žiaka, resp. toleranciu nejednoznačnosti, na nepredvídatel’né javy, s ktorými sa žiak stretáva každej hodine cudzojazyčnej výučby pri riešení rôznych úloh a zvládaní rozmanitých komunikačných situácií . Výskum v tomto smere sa orientuje na zist'ovanie vplyvu kognitívnej premennej tolerancie nejednoznačnosti na celkovú úspešnost' v cudzom jazyku (Liu, 2012; Brown, 2000 a i.), na zist'ovanie vplyvu tolerancie nejednoznačnosti na komunikačné zručnosti a cudzojazyčný prejav (Brown, 2000; Liu, 2012 a i.), zist'ovanie vplyvu tolerancie nejednoznačnosti na syntaktickú zručnost', resp. skladbu vety v cudzom jazyku a porozumenie súvetiam (Stranovská a kol., 2013).

Kreativitu chápeme ako zručnost', ktorá by mala byt' súčastou vzdelávania na všetkých učitel'ských fakultách. Po absolutóriu ju považujeme za neoddelitel'nú súčast' kompetencie učitel'a. Preto sme túto zručnost' ako jednu $\mathrm{z}$ dôležitých zložiek kompetenčného profilu učitel'a zaradili aj do portfólia hodnotiacich kritérií, ktoré zostavujeme v rámci projektu APVV -14-0446 Hodnotenie kompetencii učitelov. Kreativitu cez prizmu kognitívneho pohl'adu považujeme za aktuálnu a potrebnú vo vyučovaní cudzieho jazyka, pretože touto cestou formujeme prirodzenú komunikáciu v cudzom jazyku, ako aj jazykovú sebaistotu budúcich učitel’ov cudzieho jazyka, ktorí následne odovzdávajú získané skúsenosti svojim žiakom. Z toho hladiska sme si stanovili za ciel' zistit' dynamiku kognitívnej premennej tolerancia nejednoznačnosti za pôsobenia programu tvorivosti $\mathrm{v}$ cudzom jazyku. Za originálne $\mathrm{v}$ tejto problematike považujeme prepojenie kognitívnej zložky $\mathrm{s}$ jazykovou.

\section{Kognitívne teórie tvorivosti}

Kognitívne teórie tvorivosti sa snažia objasnit' rôzne aspekty myslenia a procesy, ktoré vplývajú na tvorivé činnosti. Zohl'adňujú najmä vplyv kognitívneho štýlu na kreatívne myslenie (Stranovská a kol., 2013). Výskum sa zameriava na vzt’ah rôznych štýlov a stratégií a ich súvis s kreativitou 
(Dacey, Lennon, 2000; Jurčová, 2006; Eysenck, Keane, 2008; Sternberg, 2009 a i.). Pozornost' sa taktiež venuje myšlienke kognitívnej paradigmy a dynamických procesov, vplývajúcich na kreativitu. Tieto procesy môžu byt' zastúpené vzájomným prepojením kognitívnych, emocionálnych, sociálnych a osobnostných faktorov.

Eysenck a Keane (2008) považujú za klúčovú v procese kreativity mentálnu stimuláciu, tzn. využívanie analógií a testovanie hypotéz. Sternberg (2009) upozorňuje na problematiku mentálneho nastavenia ako prekážky tvorivosti. Jednotlivci majú tendenciu prirad'ovat' novému riešeniu úlohy určité mentálne nastavenie. Mentálne nastavenie môže predstavovat' zablokovanie, fixáciu, či stereotyp. Pokial' majú jednotlivci zablokované mentálne nastavenie, fixujú sa na stratégiu, ktorá sa osvedčila pri riešení viacerých úloh a nedokážu postrehnút', že na riešenie d’alšej úlohy už overená stratégia nemá dostatočný kreatívny potenciál. Dacey a Lennon (2000) uvádzajú desat' vlastností, ktoré majú vplyv na tvorivý proces: tolerancia nejednoznačnosti, stimulačná sloboda, funkčná sloboda, flexibilita, ochota riskovat', preferencia chaosu, oddialenie uspokojenia, upustenie od rodových stereotypov, vytrvalost', odvaha. Jurčová (2006) uvádza, že problém nie je v tom, či zistené charakteristiky vystihujú alebo nevystihujú tvorivú osobnost', ale aká je ich jedinečná konštelácia u jednotlivcov a ich prepojenie na konkrétne situácie a reálne činnosti.

Aj v súčasnom chápaní, definovaní či hodnotení tvorivosti sa neustále využívajú špecifické schopnosti, resp. kategórie definované Guilfordom (1968). Tento kognitívny aspekt nebol doteraz prekonaný a neustále sa v praxi využíva. Ide o nasledovné kategórie:

Figurálna a sémantická elaborácia (spracovanie určitého námetu, schémy, dokreslenie figúry, vymyslenie postupu a pod.); Slovná plynulost', fluencia (vymenovanie slov končiacich sa alebo začínajúcich sa určitými hláskami. Ide o schopnost' pohotovo si vybavovat' zo svojej slovnej zásoby množstvo slov bez ohladu na ich sémantický obsah.); Ideačná plynulost' (vybavenie si pojmov, predstáv určitej kategórie); Spontánna obrazová flexibilita (pružnost' vnímania a predstavovania si); Spontánna sémantická flexibilita (pružnost' významu, ktorá sa prejavuje schopnost'ou pohotovo vytvorit' nový variant k obsahu literárneho diela, vymysliet' alternatívne použitie určitého predmetu, redefinovat', modifikovat' určitú informáciu a pod.); Asociačná plynulost' (schopnost' rýchlo si vybavovat' asociácie $\mathrm{k}$ určitému podnetu, napr. nachádzat' $\mathrm{k}$ daným lexikálnym jednotkám synonymá, resp. antonymá a pod.); Expresívna plynulost' (spôsobilost' vymysliet' rýchlo krátke vety $\mathrm{z}$ danej zostavy písmen, pohotovo vytvorit' slová z určitých koncoviek na princípe retrográdneho slovníka a pod.); Obrazová adaptívna flexibilita (spôsobilost' rekonštruovat' dané obrazce. Prejavuje sa v úlohách, v ktorých je potrebné reorganizovat' súbor vizuálnych podnetov a pod.); Symbolická adaptívna flexibilita (sémantická transformácia, napr. transformácia správy obmedzená určitými podmienkami); Originalita (inovatívnost', pri hodnotení sa posudzuje pôvodnost' výkonu).

\subsection{Teória kreatívneho transdisciplinárneho myslenia}


Novšie prístupy k tvorivosti (Henriksen, Mishra, Fisser, 2016) akcentujú transdisciplinárny rozmer kreativity, ktorý sa aplikuje i vo vyučovaní cudzieho jazyka. Pre učenie sa a vyučovanie cudzieho jazyka je táto teória mimoriadne prínosná, pretože ide o synergiu poznatkov z rôznych oblastí, ktoré môžu byt' založené aj na kauzálno-logickom princípe. Ich následné generovanie do nových poznatkov spíña kritéria novosti, hodnoty a sociálnej užitočnosti. Jedným zo spôsobov, ako sa môže rozvíjat' kreatívne transdisciplinárne myslenie je prepojenie súboru logických a verbálnych zručností. Ide o súbor kognitívnych nástrojov, ktoré vytvoril Root-Bernstein (Root-Bernstein, 2003, 2006). Patria k nim:

1) Pozorovanie, ktoré si vyžaduje nielen samotné pozorovanie, ale aj porozumenie. Pri porozumení je potrebné venovat' osobitnú pozornost' prirodzenej zvedavosti a vnímaniu informácií, ktoré jednotlivec získava senzoricky. Potom nasleduje vizualizácia, resp. schopnost' vytvárat' si dojmy, ktoré pozorujeme, bez toho, aby boli prítomné vonkajšie stimuly. Jednotlivci si môžu predstavovat' rozličné skutočnosti prostredníctvom vizuálnych, sluchových, čuchových, chut'ových a kinestetických vnemov. Pozorovanie ako aj vizualizácia sa môžu zlepšovat' nácvikom.

2) Tvorba vzorov - tento nástroj funguje na základe rozpoznávania a vytvárania vzorov. Rozpoznávanie predstavuje analytickú čast' procesu tvorby, zatial' čo samotné vytváranie predstavuje tvorivú, inovačnú hru. Proces formovania vzorov začína, ked’ sa pravidelne kombinujú rozličné zložky a procesy s ciel'om vytvorit' určitý vzor. Kreatívni spisovatelia a básnici sa spoliehajú na vedomosti o lingvistických (sémantických) vzoroch a štruktúrach, ktoré im pomáhajú vymysliet' fiktívny príbeh, či vytvorit' originálnu báseň.

3) Abstraktné myslenie predstavuje schopnost' zachytit' základnú podstatu veci. Najdôležitejšou častou tohto procesu je tvorba analógií a schopnost' nájst' podobné črty medzi predmetmi, ktoré sa od seba líšia.

4) Prepojené myslenie (stotožnenie sa s niekým), aplikácia tohto nástroja obvykle súvisí s dvomi zručnostami: kinestetickým myslením a empatiou. Kinestetické myslenie predstavuje myslenie rečou tela, pri ktorom jednotlivci nielen opisujú to, čo vidia, ale aj to, čo vnímajú. Ďalším stupňom prepojeného myslenia je empatia, pri ktorej si jednotlivci majú predstavit' seba v „koži niekoho iného“, resp. „prevtelenia sa“ do niekoho iného.

5) Modelovanie je nástroj, ktorý vychádza z informácií získaných pomocou predchádzajúcich kognitívnych nástrojov. Vychádza z používania analógií a aparátu priestorového myslenia, ktoré zobrazuje naše myslenie vo vzt’ahu $\mathrm{k}$ priestoru a času. Priestorové myslenie sa spája s abstraktným myslením a analógiami. Prispieva k vytváraniu modelov vecí a procesov, ktoré môžu pomôct' objasnit' chápanie skutočného sveta.

6) Hra je nástroj, ktorý v sebe zahŕňa zapájanie vedomostí, reči tela, mysle a taktiež predstavuje schopnost' precítit' radost' z ich realizácie. Ked' sa tvoriví jednotlivci zaoberajú rôznymi myšlienkami alebo konceptmi, naskytne sa im jedinečná príležitost' objavit' nové spôsoby myslenia. Kreatívni jednotlivci sa $\mathrm{v}$ rôznych disciplínach často odvolávajú na hodnotu hry. Prostredníctvom hry majú príležitost' premenit' myšlienky na tvorivé činy alebo nové poznatky. 
7) Syntéza je finálnym kognitívnym nástrojom, ktorý spája nástroje opísané vyššie. Predstavuje zoskupenie rôznych spôsobov poznávania do syntetizovaného poznania. Ked' určitej skutočnosti rozumieme, naše pocity, zmysly, poznatky a skúsenosti sa spájajú do mnohotvárneho a súdržného druhu poznania. Tento tvorivý proces obvykle opisujú umelci, spisovatelia a vedci, ked’že práve oni spájajú vizuálne, sluchové, čuchové, chutové, kinestetické vnemy a emócie do celku, cez estetické a intelektuálne zážitky. Ak sú myslenie a cítenie navzájom prepojené, kreatívne a intelektuálne procesy sa stávajú intenzívnejšími a môžeme ich označit' ako syntetizujúce.

Súbor týchto kognitívnych nástrojov možno aplikovat' vo vyučovaní cudzieho jazyka prostredníctvom podpory premennej tolerancia nejednoznačnosti.

\subsection{Tolerancia nejednoznačnosti}

Jednotlivec $\mathrm{v}$ procese učenia sa cudzieho jazyka spracováva abstraktnú štruktúru cudzieho jazyka, poznáva kultúru ciel'ového jazyka, vytvára si vzt’ah k jazyku a kultúre, snaží sa analyzovat', dedukovat' a následne syntetizovat' poznatky v cudzom jazyku. Na základe týchto skutočností si jednotlivec postupne vytvára identitu cudzieho jazyka a kultúry, tzn. uvedomuje si, do akej miery je pre neho cudzí jazyk neurčitý, neznámy, cudzí a do akej miery je mu cudzí jazyk blízky. V tomto procese zohráva dôležitú úlohu premenná neistota.

Tolerancia nejednoznačnosti hovorí o spôsobe jednotlivca (i celej skupiny) vnímat' a spracovávat' informácie o neurčitých stimuloch a situáciách, alebo o situáciách, ktoré sú považované za neurčité, ak dochádza ku konfrontácii so zoskupením neznámych, komplexných alebo inkongruentných klúčov (Stranovská a kol., 2013). Tolerancia nejednoznačnosti v cudzom jazyku predstavuje jeden $\mathrm{z}$ učebných štýlov, schopnost' jednotlivca tolerovat' nejednoznačnost', vytvárat' kognitívnu štruktúru. To znamená schopnost' samostatne pracovat's novými podnetmi bez pocitu frustrácie, ktorá úzko súvisí s kreativitou. Bar-Tal (1994) poukazuje na kognitívnu štrukturáciu ako proces, ktorý ul'ahčuje dosiahnut' istotu filtráciou neadekvátnych informácií a tvrdí, ked' osoba postupne spracováva informácie, informácia sa asimiluje v poznávacej štruktúre a stáva sa použitel’nou. Ak je človek vybavený jednoduchým a rigidným systémom kognitívnej štrukturácie, tak používa stále tie isté konštrukty a robí stále tie isté chyby. Výskumy preukázali, že ludia s vyššou úrovňou kognitívnej štrukturácie disponujú lepšími komunikačnými zručnostami a lepšie zvládajú stresové a zátažové situácie (Výrost, Ruisel, 2000). Liu (2012) pripisuje dôležitost' v súvislosti $\mathrm{s}$ toleranciou nejednoznačnosti faktoru rizika $\mathrm{v}$ procese učenia sa cudzieho jazyka. Vo výskume zistil, že faktor rizika pozitívne vplýva na výkon v angličtine vysokoškolských študentov. Študenti, ktorí riskujú sú ochotnejší zapájat' sa častejšie do komunikácie v cudzom jazyku. Faktor rizika v procese učenia sa cudzieho jazyka znamená schopnost' jednotlivca odpútat' sa od používania stereotypných výrazových prostriedkov, experimentovat' s používaním jazykových fráz, vetných štruktúr a rozvíjat' lingvistickú tvorivost'. Toto zistenie nás motivovalo k podpore kreativity a tolerancie nejednoznačnosti metódami kreativity. 


\section{Metódy rozvíjania tvorivého potenciálu žiakov, tolerancie nejednoznačnosti a ich aplikácia vo vyučovaní cudzieho jazyka}

Stimulácia a rozvíjanie tvorivého potenciálu žiakov, ich tolerancie nejednoznačnosti predstavuje široko rozvetvenú oblast' tvorivosti z kognitívneho pohl'adu. Práve túto oblast' výskumu tvorivosti považujeme za kl'účovú, pretože jej podstatnou úlohou je nájst' spôsoby, ako objavit' v každom žiakovi jeho vlastné zdroje, potenciál tvorivej činnosti, pomôct' mu uvol'nit' ich a rozvinút'. Existujú rôzne postupy tvorivého riešenia problémov. Medzi najznámejšie podl'a Zelina (1994) patria metódy založené na princípoch klasického brainstormingu a jeho rôznych modifikácií a metódy tvorivého riešenia problémov (klasický brainstorming, jeho písomná varianta brainwriting, synektika Gordona, metóda Philips 66, metóda HOBO, heuristická metóda Polyu, heuristická metóda Matrice explorácie Povilejka, heuristika IDEALS Nadlera, INVENTIKA funkcionálna analýza Fustierovcov a d'alšie). V psychologickej a pedagogickej literatúre sú prezentované rôzne metódy rozvíjania tvorivosti. Zelina (1994) ich rozdel'uje na viaceré skupiny: Metódy tvorby divergentných úloh; Metódy, ktoré obsahujú úlohy na dôvtip a antirigidné myslenie (zvyčajne ide o úlohy konvergentné, ale riešenie v sebe obsahuje niečo neobvyklé); Metódy na rozvíjanie vnímania, senzitivity, otvorenosti k vonkajšiemu a vnútornému svetu, citlivosti postrehu, cvičenie asociačnej, percepčnej a apercepčnej pohotovosti; Metódy rozvíjania fantázie, imaginácie, predstavivosti; Metódy podpory fluencie, flexibility, originality a elaborácie pri myšlienkovej produkcii; Metódy tvorivého riešenia problémov, kde sú základom heuristické a iné metódy.

Ked’že v našom príspevku primárne hovoríme o stimulácii kreatívneho potenciálu budúcich učitel'ov cudzích jazykov na základných a stredných školách, o stimulácii tolerancie nejednoznačnosti, pri prezentácii jednotlivých aktivít vychádzame z faktu, že študenti už majú osvojenú všeobecnú slovnú zásobu na relatívne dobrej úrovni. Pri aplikácii kreatívnych foriem výučby sledujeme dva ciele: rozvoj komunikačnej kompetencie a rozvoj kreatívneho potenciálu. Rozvoj komunikačnej kompetencie sa dosahuje rozširovaním tzv. nadstavbovej slovnej zásoby $\mathrm{v}$ jednotlivých tematických okruhoch, senzibilizáciou študentov pre rozpoznávanie slov v rôznych štylistických registroch, včítane expresív a slangových výrazov (okrajovo aj pluricentrických variantov jazyka, napr. britská vs. americká angličtina), rozširovaním ich znalosti $\mathrm{v}$ interkultúrne determinovaných rozdieloch $\mathrm{v}$ jazykových konvenciách $\mathrm{v}$ ústnej komunikácii (akoby reagoval a čo by povedal Angličan, resp. Američan

v konkrétnej situácii) a v textových konvenciách v písomných prejavoch. Tento ciel' je zameraný predovšetkým na autenticitu prejavu.

\section{Výskum tolerancie nejednoznačnosti}

Náš výskum sme zamerali na skúmanie premennej tolerancie nejednoznačnosti za pôsobenia programu tvorivosti v cudzom jazyku. Zist’ujeme, aký vplyv má pôsobenie zámernej stimulácie metód tvorivosti v cudzom jazyku na schopnost' vytvorenia kognitívnej štruktúry, t.j. 
toleranciu nejednoznačnosti (na neurčitost', či je jednotlivec schopný štruktúrovat’ informácie o neurčitých stimuloch a situáciách).

Vychádzame pritom zo Sarmányho a Jurčovej teórie a výskumov kognitívnych štýlov (Jurčová, Sarmány-Schuller, 1993 a i.), v ktorých sa tvrdí, že vzt’ah inovatívnosti a ochoty riskovat' v sociálnych situáciách si vyžaduje od jednotlivcov prekročenie stereotypov a pristúpenie $\mathrm{k}$ zmene (ochota menit' svoje zaužívané zmýšl'anie, spôsoby správania a postoje), vyrovnat' sa s nejednoznačnost'ou, neurčitost'ou a neistotou v sociálnych situáciách.

$\mathrm{Na}$ základe vyššie uvedeného ciel’a sme si stanovili hypotézu: Predpokladáme, že pôsobenie metód tvorivosti v cudzom jazyku sa prejaví vo vyššej tolerancii nejednoznačnosti.

Hypotézu sme testovali párovým t-testom na vzorke 102 študentov UKF v Nitre vo priemernom veku 21,5 rokov $(2 .-4$. ročník), pričom študenti tvorili tri experimentálne a tri kontrolné skupiny: (ES I: experimentálna skupina I, študenti učitel'stva, v kombinácii cudzí jazyk a predmet na Pedagogickej fakulte, 15 študentov; ES II: experimentálna skupina II, študenti učitel'stva, v kombinácii predmetov Filozofickej fakulty, 17 študentov; ES III: experimentálna skupina III, študenti učitel'stva, v kombinácii predmetov Filozofická fakulta a fakulta prírodných vied, 12 študentov; obdobné boli i kontrolné skupiny, KS I: 18 študentov, KS II, 23 študentov, KS III 17 študentov).

Toleranciu nejednoznačnosti sme zistovali metódou Škála schopnosti vytvorenia kognitivnej schopnosti (AACS), ktorej autorom je Yoram Bar-Tal (1994), o slovenský preklad a adaptáciu sa zaslúžil Ivan Sarmány-Schuller. Obsahuje 24 položiek. Jednotlivé položky hodnotia respondenti na šest'bodovej škále. Položky charakterizujú l'ahkost'v použivaní kognitívnych štruktúr (napr. Zvyčajne nemávam dostatočné nápady po tom, čo urobím nejaké rozhodnutie), t’ažkosti s kognitívnym štruktúrovaním (napr. Hoci ma rozhodovanie, ktoré mám urobit' obt'ažuje, je pre mňa t'ažké rozhodnút' sa a oslobodit' sa od t'ažkostí.), l'ahkost'v použivaní postupných procesov (napr. Zvyčajne sa presvedčím, že moja práca je opatrne naplánovaná a dobre zorganizovaná), t’ažkosti s použivaním postupných procesov (napr. Aj ked'si urobím zoznam vecí, ktoré mám urobit', je pre mňa t’ažké ich vykonat').

$\mathrm{V}$ experimentálnej skupine sme aplikovali program tvorivosti v cudzom jazyku, v kontrolnej skupine sme tento program nerealizovali. Výskumné merania sa uskutočnili v experimentálnej a kontrolnej skupine $\mathrm{v}$ úvode a po ukončení programu. Postupovali sme nasledovne: vypracovanie programu, vol'ba vhodných metód, prvé meranie, druhé meranie.

Graf 1 : Štatistická významnost' rozdielov v AACS v 1. a 2. meraní (Študentov párový t-test) 


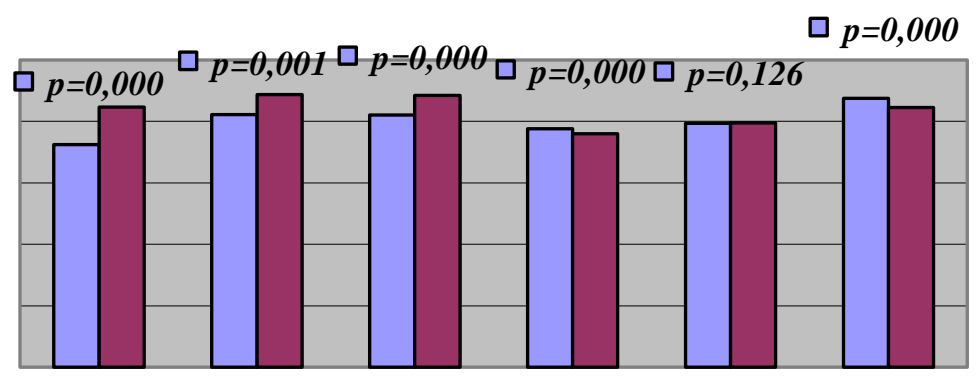

\section{$\square$ 1.meranie}

\section{Legenda:}

ES I: experimentálna skupina I (študenti učitel'stva, v kombinácii cudzí jazyk a predmet na Pedagogickej fakulte)

ES II: experimentálna skupina II (študenti učitel'stva, v kombinácii predmetov Filozofickej fakulty)

ES III: experimentálna skupina III (študenti učitel'stva, v kombinácii predmetov Filozofická fakulta a fakulta prírodných vied)

KS I: kontrolná skupina I (študenti učitel'stva, v kombinácii cudzí jazyk a predmet na Pedagogickej fakulte)

KS II: kontrolná skupina II (študenti učitel'stva, v kombinácii cudzí jazyk a predmet na Filozofickej fakulte)

KS III: kontrolná skupina III (študenti učitel’stva, v kombinácii cudzí jazyk a predmet na Fakulte prírodných vied)

1. meranie - meranie pred realizáciou programu tvorivosti v cudzom jazyku

2. meranie - meranie po realizácii programu tvorivosti v cudzom jazyku AACS - tolerancia nejednoznačnosti

Štatisticky významný rozdiel medzi prvým a druhým meraním sa prejavil smerom $\mathrm{k}$ vyššej tolerancii nejednoznačnosti budúcich učitel’ov cudzieho jazyka v kombinácii s predmetom na Pedagogickej a Filozofickej fakulte po absolvovaní programu tvorivosti $\mathrm{v}$ cudzom jazyku. Budúci učitelia Pedagogickej a Filozofickej fakulty sa po absolvovaní programu tvorivosti v cudzom jazyku preukázali väčšiu mieru schopnosti adekvátne štruktúrovat' informácie o neurčitých stimuloch a situáciách a s väčšiu mieru zručnosti dosiahnut' istotu $\mathrm{v}$ nejednoznačných situáciách, resp. dokázali v rôznych komunikačných aktivitách uvažovat' flexibilne. Tieto zistenia pripisujeme aplikácii metód inscenačných hier, didaktických kreatívnych hier, metód metaforického myslenia, myšlienkových máp ako aj projektovej práce, ktoré podnietili budúcich učitel'ov k sebareflexii, rozmýšl'aniu nad svojimi ciel'mi, organizovaním života, stanovením d’alších ambícií, čo zároveň viedlo $\mathrm{k}$ presahovaniu stereotypov, podpore myšlienkovej flexibility, nárastu a posilneniu nezávislého správania. Budúcich učitel’ov cudzieho jazyka motivovalo absolvovanie programu tvorivosti $\mathrm{k}$ uvedomeniu si svojho jazykového správania, tzn. do akej miery sú scudzím jazykom identifikovaní, do akej miery vnímajú jeho štruktúru, jeho špecifické 
lexikálne a gramatické javy, čím sa stávali tolerantní k spracovávaniu informácií o neurčitých stimuloch. Stranovská a kol. (2013) konštatujú, že jednotlivci s vysokou toleranciou nejednoznačnosti vnímajú neurčité situácie ako žiaduce, zaujímavé, pôsobiace ako výzvy, neodmietajú ich, ani pritom inkongruencia nenarušuje ich komplexnost'.

Vzostup tolerancie nejednoznačnosti budúcich učitel'ov cudzieho jazyka v kombinácii s Fakultou prírodných vied sa prejavil, ale bez štatistickej významnosti. Tento fakt môže na jednej strane súvisiet's vyššími hodnotami v sledovanej oblasti v úvode programu. Na druhej strane sa javí, že naša výskumná vzorka študentov prírodných vied v kombinácii s cudzím jazykom disponuje vyššou toleranciou nejednoznačnosti a schopnost'ou riskovat' v nejasných úlohách. Istú súvislost' vidíme $\mathrm{v}$ odlišných spôsoboch myslenia a uvažovania u študentov prírodných vied v porovnaní so študentmi pedagogických, teda humanitne orientovaných vied. Tento postreh je však nevyhnutné exaktne verifikovat', čo otvára cestu do d’alšieho výskumu. Porovnaním kontrolných skupín (bez realizácie programu) s experimentálnymi skupinami (graf 1) nezistujeme štatisticky významný posun $\mathrm{v}$ kontrolnej skupine, resp. $\mathrm{v}$ kontrolných skupinách neprišlo k zvýšeniu schopnosti adekvátne štruktúrovat' informácie o neurčitých stimuloch a situáciách.

\section{Záver}

V kontexte súčasných edukačných ciel'ov prípravy budúcich učitel’ov cudzieho jazyka tvorí nezanedbatel’nú zložku podpora kreatívneho prístupu $\mathrm{k}$ učeniu vo všetkých jeho fázach. Podstatnú úlohu v tejto zložke zohráva kognitívne hl'adisko v synkréze s emóciami, pretože nestačí sa s metódami na rozvoj tvorivého myslenia počas prípravy na učitel'ské povolanie len oboznámit', ale je nevyhnutné si ich osvojit', resp. sa v nich kognitívne ukotvit' a emocionálne ich prežívat', aby ich budúci učitelia boli následne pripravení aplikovat' ich vo svojej učitel'skej praxi. Kognitívne ukotvit' znamená kognitívne štruktúrovat', resp. spracovat' ich obsahy, tolerovat' $v$ ich procese nejednoznačnosti a stotožnit' sa s ich významom pre stimuláciu myslenia. Tieto atribúty považujeme za klúčové v rozvíjaní kreativity cez prizmu kognitívneho pohl'adu vo vyučovaní cudzieho jazyka ako aj počas prípravy budúcich učitel'ov cudzieho jazyka. Z týchto dôvodov sme sa zamerali na ich analýzu a skúmanie kognitívnej premennej tolerancia nejednoznačnosti. Proces kognitívneho ukotvenia si v kreatívnom prístupe vyžaduje, aby si budúci učitelia metódy na rozvoj tvorivého myslenia vyskúšali a prežívali ich vlastnou skúsenost’ou. Preto sme aplikovali program tvorivosti v cudzom jazyku a usilovali sme sa za jeho stimulácie skúmat' dynamiku tolerancie nejednoznačnosti.

Veríme, že prostredníctvom kognitívneho ukotvenia sa v kreatívnych prístupoch vyučovania cudzieho jazyka a emocionálneho preživania, dokážu budúci učitelia cudzieho jazyka po skončení štúdia aj svojim žiakom sprostredkovat' cudzojazyčné znalosti cez tvorivý prístup a kognitívny pohl'ad. 
This work was supported by the Slovak Research and Development Agency under the contract No. APVV-14-0446.

\section{Bibliographic references}

BAR-TAL, Y. 1994. The effect of need and ability to achieve cognitive structure on mundane decision making. European Journal of personality, 8, pp. 45-58.

BIRDSELL, B. 2013. Motivation and Creativity in the Foreign Language Classroom. FLLT Conference Proceedings. 2, LITU, Bangkok, pp. 887-903. BIROVA, J. - ELIASOVA. 2014. Plurilingual and Pluricultural Competence and Foreign Language Teaching at Primary and Secondary Schools in Slovakia. In XLinguae. Vol. 7, no. 1, pp. 75-82. ISSN 1337-8384.

BROWN, H. D. 2000. Principles of language learning and teaching (4th ed.). Longman, New York.

CLARKE, M. A. 2012. Creativity in modern foreign languages teaching and learning. The Higher Education Academy corporate culture. In: Journal of Marketing, 73, pp. 3-23.

CACKA, O., et al. 1999. Psychologie imaginatívni vychovy vzdelavani s priklady aplikace. Brno: Doplnek. 368 p.

DACEY, J. S. - LENNON, K. H. 2000. Kreativita. Praha: Grada. 252 p.

EYSENCK, M. W. - KEANE, M. T. 2008. Kognitivni psychologie. Praha: Academia.

FRYDRYCHOVA KLIMOVA, B. 2013. Developing thinking skills in the Course of Academic Writing. Procedia - Social and Behavioral Sciences, 3rd World Conference on Learning,Teaching and Educational Leadership, pp. 508-511.

GADUSOVA, Z. - HASKOVA, A. 2015. Training Educational Staff: Vision and Reality in Pre-service and In-service Training. In: EDULEARN15 Proceedings. IATED Academy, pp. 2046 - 2053.

GUILFORD, J. P. 1950. Creativity. American psychologist, 5, pp. 444-454. GUILFORD, J. P. 1968. Intelligence, creativity, and their educational implications. Robert R. Knapp, San Diego.

HENRIKSEN, D. - MISHRA, P. - FISSER P. 2016. Infusing Creativity and Technology in 21 st century Education : A systemic view for change. Educational technology and Society. 19(3), pp. 27-37.

HLAVSA, J. - JURCOVA, M. 1978. Psychologicke metody zistovania tvorivosti. Psychologicke a didakticke testy, n.p., Bratislava.

HUSS, J. A. 2008. Getting Serious About Humor: Attitudes of secondary teachers towards the use of humor as a teaching strategy. In: Journal of Ethnographic and Qualitative Research, 3 (1), pp. 28-36.

JURCOVA, M. - SARMÁNY SCHULLER, I. 1993. Kognitívny styl „sirka kategorizacie“. Ceskoslovenska psychologie, 37 (1), pp. 1-13.

JURCOVA, M. 2002a. Sucasne trendy psychologie tvorivosti. Ceskoslovenska psychologie, 46, pp. 385-403.

JURCOVA, M. 2002b. Torranceho figuralny test tvoriveho myslenia. Prirucka: Vseobecna cast. Bratislava: Psychodiagnosticke a didakticke testy, n. p. Bratislava. 
JURCOVA, M. 2006. Slovak Entrepreneurs - Pioneers. In: Creativity and Innovation Management, 5 (2), pp. 134-141.

LAKOFF, G. - JOHNSON, M. 1980/2003. Metaphors We Live By. Chicago: University of Chicago Press.

LALINSKA, M. 2013a. Meranie a hodnotenie vysledkov cudzojazycnej edukacie v primarnom vzdelavani. In: Philologia, 23 (2), pp.101-114.

LALINSKA, M. 2013b. Psychometricke analyzy testov z cudzieho jazyka. In: XLinguae: European Scientific Language Journal, 6 (3), pp. 21-31.

LEWIS, T. 2008. Creativity in technology education: Providing children with glimpses of their creative potential. International Journal of Technology and Design Education. [http:// DOI 10.1077/S10798-008-9051-y].

LITTLEMORE, J. - LOW, G. 2006. Metaphoric Competence, Second Language Learning, and Communicative Language Ability. Applied Linguistics, 27 (2), pp. 268-294.

LIU, M. 2012. Predicting effects of personality traits, self-esteem, language class risk-taking and sociability on Chinese university EFL learners' performance in English. Journal of Second Language Teaching and Research, $1(1) .30 \mathrm{p}$.

MUGLOVA, D. a kol. 2010. Cudzie jazyky s detmi kreativne a hravo. Nitra: FF UKF. $113 \mathrm{p}$.

MUGLOVA, D. - MALA E. - STRANOVSKA, E. 2017. Creativity in Teaching Languages. In: Journal of Human Dignity and well-being. - ISSN 2451-3520, Vol. 3, no. 1 (2017), pp. 18-34.

POPPEROVÁ JURCOVA, M. 1969. Niektore psychologicke problemy tvorivych schopnosti. Kandidatska dizertacna praca. Bratislava: FF UK.

ROOT-BERNSTEIN, R. S. 2003. The art of innovation: Polymaths and the universality of the creative process. In L. Shavanina Roweton, W. Creativity: A review of theory and research (Report No. 24). Routledge Falmer.

ROOT-BERNSTEIN, R. S. 2006. Imaginary worldplay in childhood and maturity and its impact on adult creativity. Creativity Research Journal 18, pp. 405-425.

RUISEL, I. - VYROST, J. 2000. Kapitoly z psychologie osobnosti. Bratislava: VEDA vydavatelstvo SAV.

RUNCO, M.A. 2014. Creativity: Theories and themes: Research, development, and practice. Academic Press, $520 \mathrm{p}$.

STERNBERG, R. J. 2009. Kognitivní psychologie. Praha: Portal.

STRANOVSKA, E. a kol. 2013. Analysis of Cognitive Structuration in Context of Verbal Productivity. Procedia - Social and Behavioral Sciences, 84(1), pp. 336-340.

THAGARD, P. 2001. Uvod do kognitívni vedy. Mysl a mysleni. Praha: Portal, $231 \mathrm{p}$.

TORRANCE, E. 1995. Why fly? A philosophy of creativity. New Jersey: Ablex Publishing Corporation, Norwood.

TORRANCE, E. 2008. The Torrance Test of Creative Thinking Norms Technical Manual Figural (Streamlined). University Press. 137 p.

WILLIAMS, S. D. 2002. Self-esteem and the self-censorship of creative ideas. Personnel Review, 31(4), pp. 495-503. 
ZELENICKA, E. - KANASOVA, D. 2010. Cudzie jazyky s detmi kreativne a hravo. (D. Muglova a kol., eds.), FF UKF Nitra, M. Vaska Presov, $113 \mathrm{p}$.

ZELINA, M. 1994. Strategie a metody rozvoja osobnosti. Bratislava: IRIS. ZIV, A. 1976. Facilitating effects of humor on creativity. In: Journal of Educational Psychology, 68(3), pp. 318-322.

prof. PhDr. Eva Malá, CSc.

Department of Language Pedagogy and Intercultural Studies

Faculty of Education

Cotantine the Phiosopher University

Drážovská cesta 4, 94974 Nitra

Slovakia

emala@ukf.sk

prof. PhDr. Daniela Müglová, CSc.

Department of Translation Studies

Faculty of Arts

Cotantine the Phiosopher University

Štefánikova 67

94974 Nitra

Slovakia

dmuglova@ukf.sk

doc. PhDr. Eva Stranovská, PhD.

Department of German Studies

Faculty of Arts

Cotantine the Phiosopher University

Štefánikova 67

94974 Nitra

Slovakia

estranovska@ukf.sk 